\title{
Shareholder Valuations of Petroleum Companies and Oilfield Services During the 2008 and 2014 Oil Price Shocks
}

\author{
Ruud Weijermars ${ }^{1, ~ *, ~ A n i t a ~ B r e s s a n ~ B o c a r d o ~}{ }^{1,2}$ \\ ${ }^{1}$ Harold Vance Department of Petroleum Engineering, Texas A \& M University, College Station, USA \\ ${ }^{2}$ State University of Santa Catarina (UDESC), Balneário Camboriú, Santa Catarina, Brazil
}

Email address:

r.weijermars@tamu.edu (R. Weijermars), anitaa_bressan@hotmail.com (A. B. Bocardo)

${ }^{*}$ Corresponding author

\section{To cite this article:}

Ruud Weijermars, Anita Bressan Bocardo. Shareholder Valuations of Petroleum Companies and Oilfield Services During the 2008 and 2014 Oil Price Shocks. Journal of Finance and Accounting. Vol. 4, No. 6, 2016, pp. 367-377. doi: 10.11648/j.jfa.20160406.17

Received: October 10, 2016; Accepted: October 25, 2016; Published: December 2, 2016

\begin{abstract}
This study analyzes the impact of the 2008 and 2014 oil price falls on the shareholder returns of diversified oil and gas majors, Canadian oil sands producers, US shale oil and gas producers and oilfield service companies. The 2008 an 2014 oil price shocks lead to capital book losses for investor TSR at year end. In both years, the TSR losses were disproportionately large as compared to the actual slow down (which was very modest) in retained earnings growth. Our recommendation is that investors should not only use $\mathrm{P} / \mathrm{E}$ ratios to identify value growth stock investment opportunities. An alternative methodology quantifies the degree of speculative valuation involved in the TSR component of capital gains (losses). When negative speculative valuations are large, future TSR growth is most likely. Companies that want to mitigate unwarranted erosion of their market capitalization due to stock price declines should ramp up advertorial efforts and point out value growth opportunities to attract investors, especially in times of depressed stock prices.
\end{abstract}

Keywords: Total Shareholder Return, Capital Gains, Dividends, Retained Earnings, Speculative Valuation

\section{Introduction}

Shareholders may instantly affect the market capitalization of a company by buying and selling the company's stock. If more investors sell a stock (supply) than buy it (demand), then the stock price will fall. Conversely, if the demand is bigger than supply, the stock price will move up. Purchase or sale of a company stock is heavily influenced by its total shareholder (TSR) performance (past, current and future expectation). The present study compares the impact on TSR of two distinct episodes of oil price shock: 2008 and 2014. Analyzing the detailed TSR changes during such events is merited because the erosion of company worth may impact their longevity as corporate entities.

The long-term price deck for Brent oil based on leading industry analyst data is given in Figure 1a. The 2008 and 2014 price shocks, distinct events of sharp price fall, are indicated in the graph. Cash cost (lower bound of price deck) is the average operating expenditure required just to maintain production from existing wells, treating development expenditure as sunk cost. Marginal cost (central curve in price deck) is calculated using companies' estimated average cost of production. Marginal cost will grow 3\% year-over-year. The estimated curve of demand destruction (DD, upper bound of price deck) is the oil price at which demand is negatively affected by high prices, which occurs, for example, when consumers stop driving due to high pump prices.

We previously investigated how the realized annual TSR in the oil and gas upstream sector was supported by actual profits realized in each year [1]. That study analyzed the average TSR for 20 oil and gas companies (Table 1) over an 11-year time series (2004-2014). The companies are assigned to four peer groups as follows: diversified oil and gas majors (Peer group A), Canadian oil sands producers (Peer group $B$ ), US shale oil and gas producers (Peer group $C$ ), and oilfield service companies (Peer group D). Our study is limited to stock-listed entities, because public data are readily available for such companies. Given the time required to complete and document a comprehensive analysis, we used fiscal year 2014 as the most complete recent year when our study was conducted in 2015/2016. 
Table 1. Peer group companies used in this study

\begin{tabular}{lc}
\hline A) Diversified Oil \& Gas Majors & NYSE Ticker Symbol \\
Exxon & XOM \\
Shell & RDS.B \\
Chevron & CVX \\
British Petroleum & BP \\
TOTAL & TOT \\
B) Canadian Oil Sands Companies & NYSE Ticker Symbol \\
Suncor Energy & SU \\
Imperial Oil & IMO \\
Canadian Natural Resources & CNQ \\
C) US Shale Oil and Gas Producers & NYSE Ticker Symbol \\
EOG Resources & EOG \\
Anadarko & APC \\
Devon Energy & DVN \\
Chesapeake & CHK \\
Encana & ECA \\
SW Energy & SWN \\
Range Resources & RRC \\
Whiting Petroleum & WLL \\
Carrizo & CRZO \\
D) Oilfield Services & SLB \\
Schlumberger & HAL \\
Halliburton & BHI \\
Baker Hughes & \\
\hline
\end{tabular}

The TSR for oil and gas companies outperformed the S\&P 500 in the first study period of relatively stable prices (20042007), except in 2006. The S\&P 500, a US market index comprising 500 companies, is regarded as the best single gauge of large-cap US equities. The average TSR for all peer groups combined (as well as maximum and minimum values) and the S\&P 500 reference TSR are given in Fig. 1b. As of 2010, the S\&P 500 reference TSR surpassed the TSR average for the oil and gas companies. The S\&P 500 company

a)

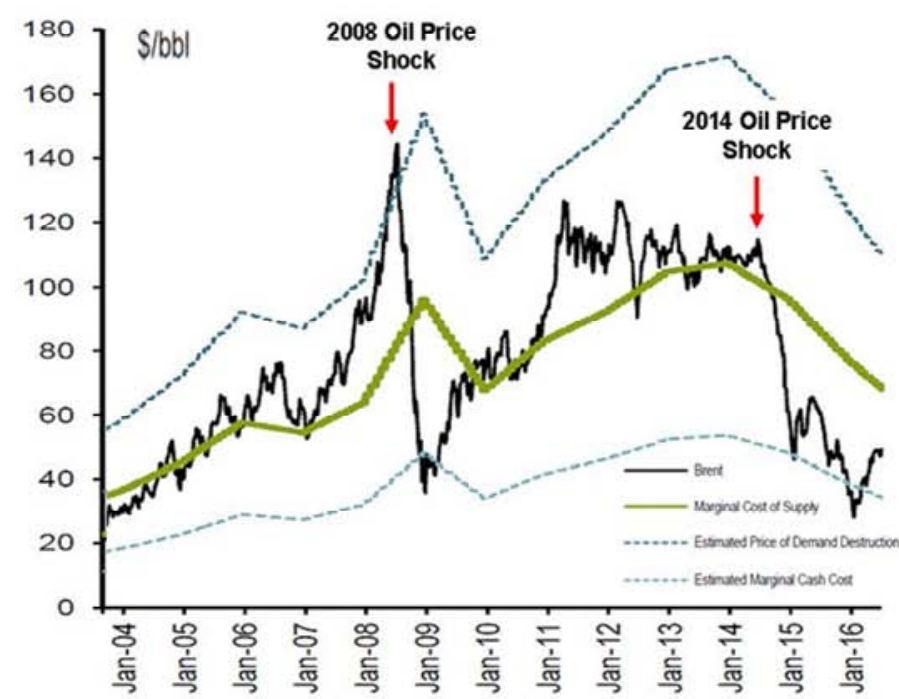

average presented the better TSR after 2010 .

Over the 11-year period previously studied by us (20042014), the TSR of the peer group companies shows a general decline (Fig. 1b). Some oil and gas companies exhibit large decreases in the TSR. For example, the 2008 recession and associated oil price fall impacted some companies such that their stock price was halved [2]. The steep reductions in company stock worth in 2008 principally occurred because of a rapid decline in oil prices. Like the oil price fall of the great recession of 2008-2009, the 2014 oil price shock negatively affected the TSR of all oil and gas companies. The peer group TSRs were affected less negatively in 2014 than in 2008. During the 2008 price shock, TSR fell 30\% lower than during the 2014 price shock. On the other hand, the 2014 TSR of all peer group companies was more deeply affected by the oil price shock than the S\&P 500 reference TSR (Fig. 1b).

This study analyzes in detail for our peer groups (Table 1) the TSR change in 2008 and 2014. Readers are referred to our companion study [1] for a full TSR analysis over the stable periods of 2004-2007 and 2009-2013 preceding the price shock years of 2008 and 2014. An in-depth review of the varying views on TSR value drivers is not attempted here, but suitable references are found in the following studies [3-8].

This study proceeds as follows. Section 2 outlines the methodology of analysis for TSR, retained earnings, and speculative valuation. Section 3 provides detailed results for each peer group and for its individual companies for the two price shock years (2008 and 2014). Section 4 places the results in perspective. Section 5 gives conclusions and provides brief recommendations for both company management and investors.

b)

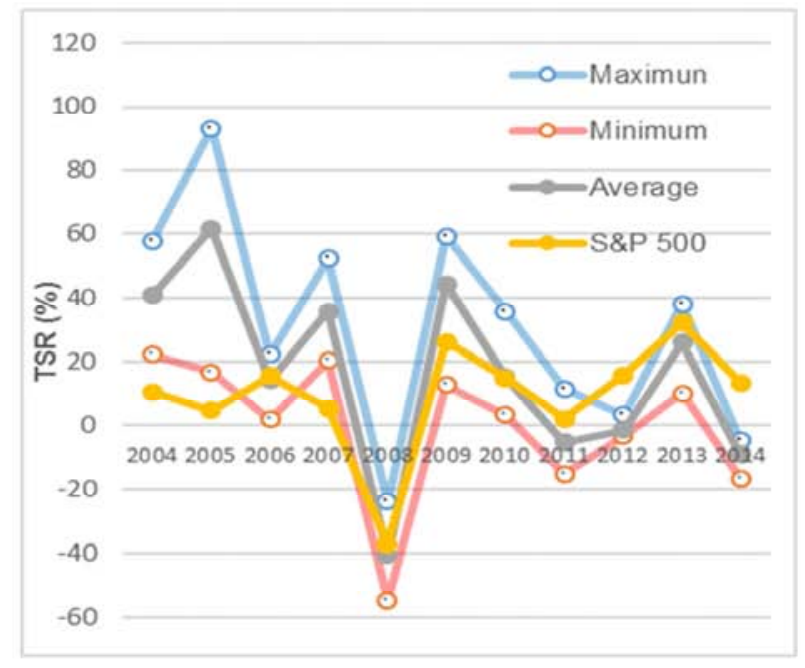

Fig. 1. a-Oil price deck for Brent oil. Source: Bernstein Research. b-Time-series (2004-2014) of the average total shareholder return (TSR) including maximum and minimum value for all peer groups combined (20 companies) compared to the S\&P 500 reference TSR. After Bocardo and Weijermars [1]. 


\section{Method of Analysis and Peer Groups}

\subsection{Method of Analysis}

The results achieved in this study are based on calculations and/or performance analysis using information available from financial websites and company reports. Financial websites used were GuruFocus, Morningstar and Y-Charts, which present time series of financial indicators exhibited annually or quarterly. When divergences were found between the values presented, a detailed comparison was made in order to identify the values matching the primary financial data available from SEC filings of each company. For example, the retained earnings from Total and BP were collected from their annual reports because they were not found in the websites used in this study. The resulting data were used in the final time series used for our analysis.

\subsection{Total Shareholder Returns}

In a first step, TSR is broken down in capital gains and dividends for each peer group and for its individual companies, using 11-year time-series. In a second step, speculative valuations are quantified using the schedule of Figure 2. The capital gains value is influenced by an increase in retained earnings and speculative valuation. Past TSR can be a strong indicator of investor's expectation of corporate performance. TSR is the return a stock brings to an investor during the holding period of an investment. TSR can be calculated by the sum of any capital gains or losses over the holding period plus any dividends (Fig. 2). Capital gains is expressed as a percentage of increase or decline in the share price:

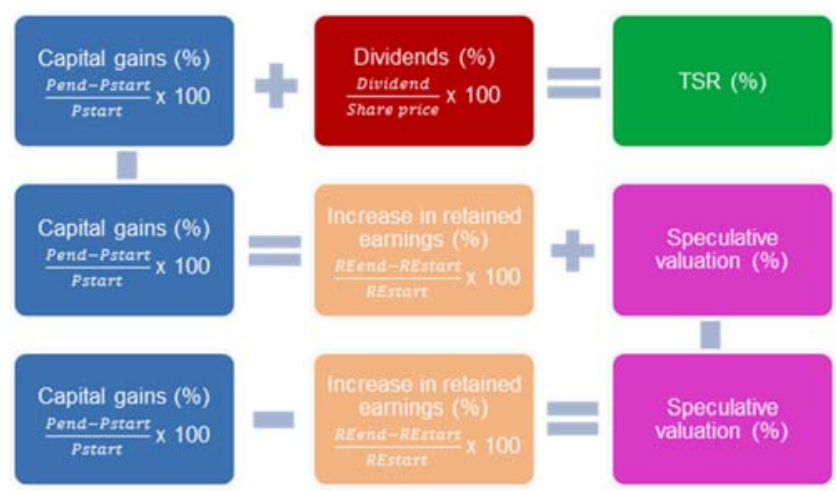

Fig. 2. Methodology followed in this study using four principal components that affect TSR. After Bocardo and Weijermars [1].

$$
\text { Capital gains }(\%)=100 \times\left[\left(\mathrm{P}_{\text {end }}-\mathrm{P}_{\text {start }}\right) / \mathrm{P}_{\text {start }}\right] \text {, }
$$

The ratio of Equation (1a) measures the increase in the value of a share that gives it a higher or lower worth than the purchase price. The dividend yield is calculated by annual dividends per share, $D_{\text {cum }}$, normalized by the price per share:

$$
\text { Dividends } \left.(\%)=100 \times\left(\mathrm{D}_{\text {cum }}\right) / \mathrm{P}_{\text {start }}\right) \text {, }
$$

The ratio of Equation (1b) measures the profitability of dividends from a company relative to the share purchase price. Stock repurchase programs enhance shareholder value by reducing the number of shares outstanding, which commonly leads to capital gains as fewer stockholders share the same basic company value but via fewer stocks outstanding to share value.

\subsection{Retained Earnings}

Retained earnings are an internal performance indicator that can be used to monitor the relative performance of companies. Such earnings are used by the company to reinvest in the business to keep growing or to pay debt. Retained earnings accumulate from the beginning of the company's existence, and are calculated by the profits that a company earned, less any dividends or other distributions paid to investors:

Ending retained earnings $=$ beginning retained earnings + net income during the period - dividends paid,

Increase in retained earnings $(\%)=100 \times\left[\left(\mathrm{RE}_{\mathrm{end}^{-}}\right.\right.$

$$
\left.\mathrm{RE}_{\text {start }}\right) / \mathrm{RE}_{\text {start }} \text {, }
$$

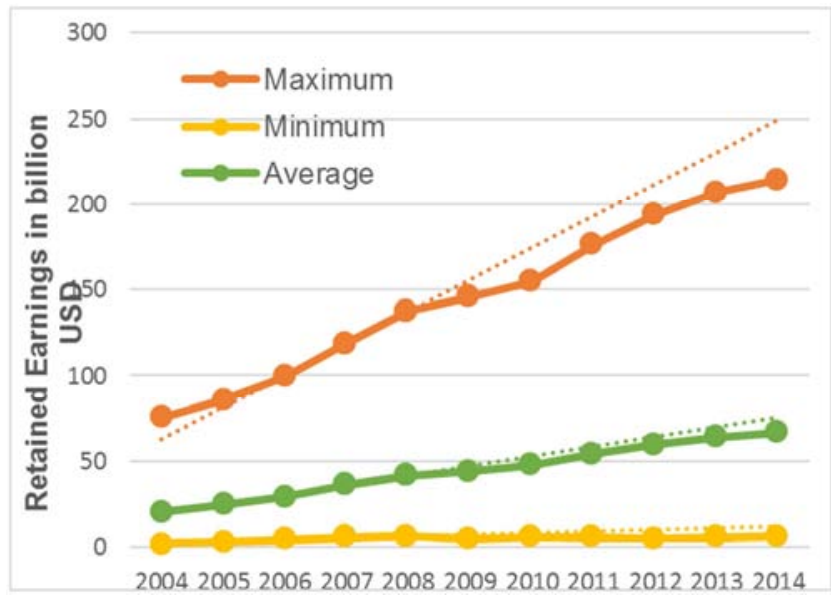

Fig. 3. Average retained earnings for all peer groups combined (plus maximum and minimum value; billion USD). Trend lines are fit for 20042008 data to highlight that the rate of increase in retained earnings has slowed down since 2008. After Bocardo and Weijermars [1].

Fig. 3 shows the average retained earnings for all peer groups combined (along with maximum and minimum value). The average is closer to the minimum curve, which means that most companies obtained retained earnings over the past decade much smaller than that of the diversified oil and gas majors (which gives the maximum curve), which are responsible for all maximum values in Fig. 3. In contrast, all minimum retained earnings can be attributed to the US shale oil and gas producers. The overall growth rate of retained earnings was negatively affected by the 2008 oil price crisis due to a decrease in net income. What stands out is that for all companies the accumulation rate of retained earnings has slowed down since 2008 (Fig. 3), which partly explains the overall decline in TSR as we move forward. 


\subsection{Speculative Valuation}

We previously investigated how the realized annual TSR (2004-2014) in the oil and gas upstream sector was supported by actual profits realized in each year [1] and quantified the differential between capital gains and retained earnings growth as speculative valuation (Fig. 2). The suggested causality is that speculative valuation of shares that is higher or lower than any past increase in retained earnings reflects investor expectation about future profits. If such profits are expected to be higher than reflected by past (retained) earnings, then positive speculative valuations prevail.

\section{(a) Capital Gains Split Majors} Stable Period 2 (2009-2013)

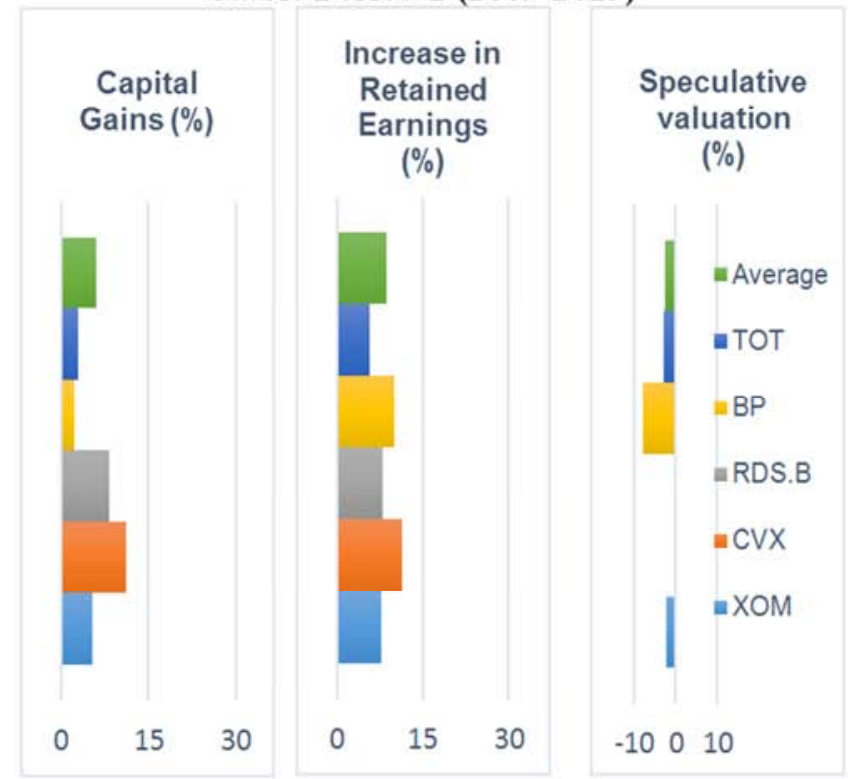

Reversely, if the majority of investors expect future profits to be lower than reflected by past retained earnings, then negative speculative valuations likely develop. Fig. 4 shows examples of the breakdown of capital gains in growth supported by an actual increase in retained earnings (retained profits) and a residual speculative valuation. In the case of Fig. 4a (oil majors), speculative valuation is negative, as the growth rate of capital gains is lower than the growth rate of retained earnings. In the case of Fig. 4b (Canadian oil sands), a more mixed pattern occurs, with some companies receiving positive speculative valuations (SNQ, SU) and others negative speculative valuation (IMO).

\section{b) Capital Gains Split Oil Sands Stable Period 2 (2009-2013)}

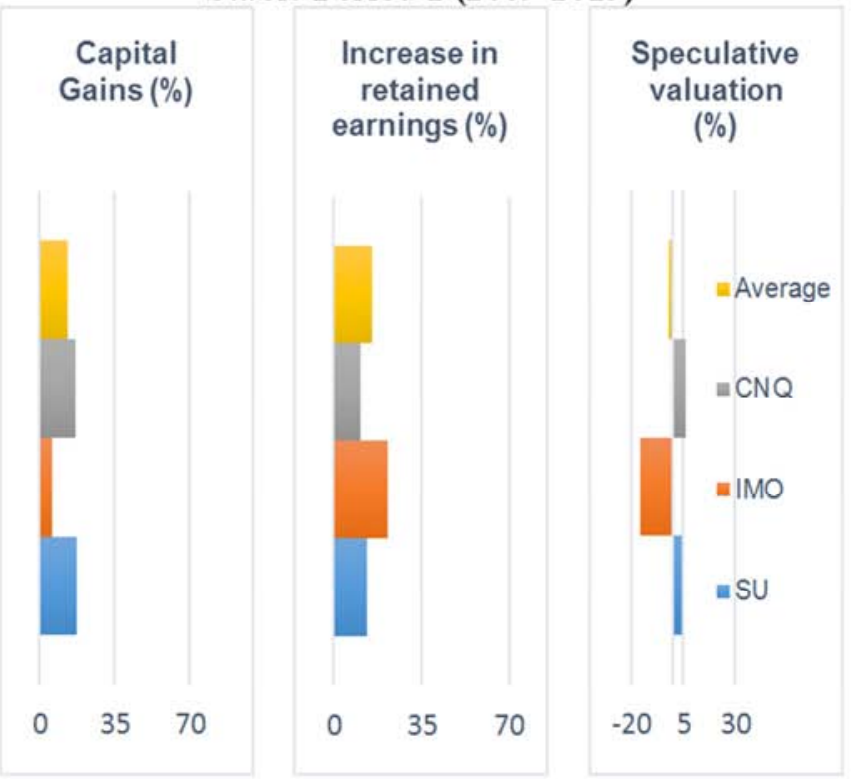

Fig. 4. a, b-Increase in retained earnings and speculative valuation as compound annual growth rate (CAGR, year over year, 2009-2013) for (a) diversified oil and gas majors and (b) Canadian oil sand operators. Increase in retained earnings minus capital gains is equal to speculative valuation.

\section{Results}

Below we discuss the detailed results of our analysis for each of the four peer groups. The study focuses on TSR and its two components: capital gains and dividends. The capital gains value is influenced by an increase in retained earnings and speculative valuation.

\subsection{Diversified Oil \& Gas Majors (Peer Group A)}

A) TSR During the Oil Price Shocks of 2008 and 2014

During the 2008 and 2014 price crises, all majors had negative TSR caused by the fall in stock prices which resulted in loss of share capital (Figs. 5a and 5b). In 2008, BP and Shell were most negatively affected. Although they awarded the two largest dividends $(7.06 \%$ and $6.07 \%$, respectively), their share capital losses $(-36.12 \%$ and $-38.04 \%)$ were larger than for other companies in the peer group which resulted in the largest TSR loss (-29.06\% and -31.97\%). By contrast, Exxon and Chevron were more resilient and had in 2008 the lowest capital losses of their peer group (-14.79\% and $-20.74 \%$, respectively). Although Exxon and Chevron awarded the smallest dividends $(1.94 \%$ and $3.42 \%)$, their TSR was less negative $(-12.85 \%$ and $-17.32 \%)$ than others in the peer group in 2008. In 2014, BP continued to deliver the lowest TSR ($15.42 \%)$, despite high dividends (6.16\%). In contrast, Shell, that had the worst TSR in 2008, improved its results by combining high capital gains $(-7.39 \%)$ and high dividends $(3.75 \%)$ to obtain the least negative TSR $(-2.04 \%)$. 
(a) TSR Split Majors 2008 Price Shock

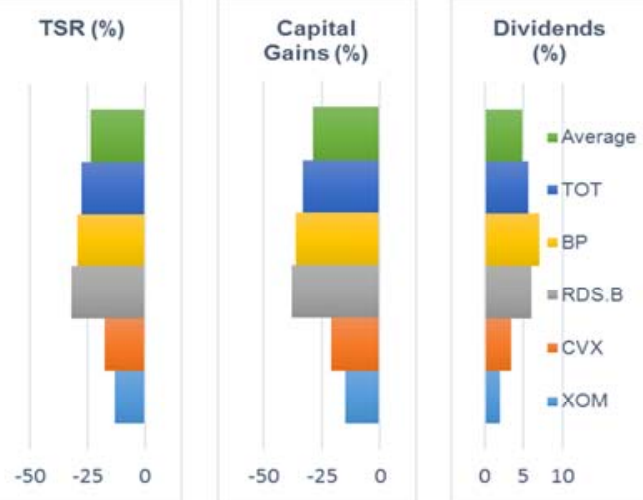

(b) TSR Split Majors 2014 Price Shock

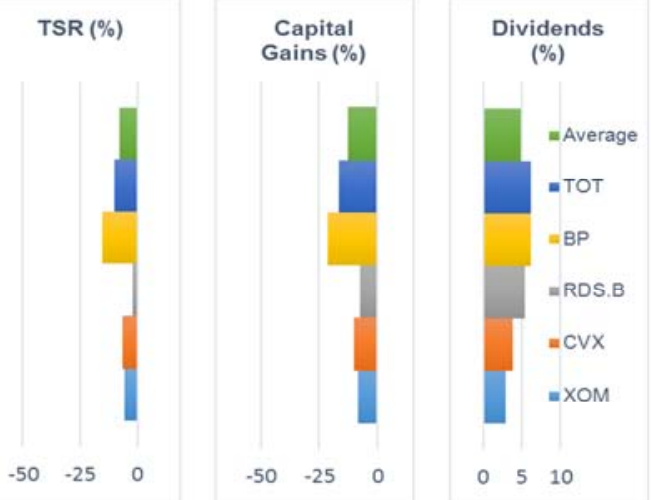

Fig. 5. a, b-TSR for diversified oil and gas majors over the two oil price shock events: (a) 2008 and (b) 2014. Breakdown of TSR contribution by each of the two components: (1) negative capital gains (capital losses) and (2) dividend yield.

B) Change in Retained Earnings and Speculative Valuation During 2008 and 2014 Oil Price Shocks

The capital gains and its components (change in retained earnings and speculative valuation) for the diversified oil and gas majors over the two crises periods are shown on Fig. 6a (2008 oil price shock) and Fig. 6b (2014 price shock). In 2008, stock prices retreated, resulting in negative capital gains (capital losses) for all oil majors in spite of positive retained earnings but depreciated by steeply negative speculative valuation. All companies still had positive growth in retained earnings, which should not have resulted in negative capital gains in 2008, were it not for negative speculation. In 2008, BP obtained the second lowest capital gains $(-36.12 \%)$ due to the largest negative speculative valuation $(-57.26 \%)$. The capital gains (loss) were not lower because of real profits resulting in a large increase in retained earnings (21.14\%). Exxon had the least negative speculative valuation $(-31.05 \%)$ which translated into the least loss of share capital (-14.79\%) compared to its 2008 peer group.

A marked difference between the 2008 and 2014 crises is

(a) Capital Loss Split Majors 2008 Price Shock

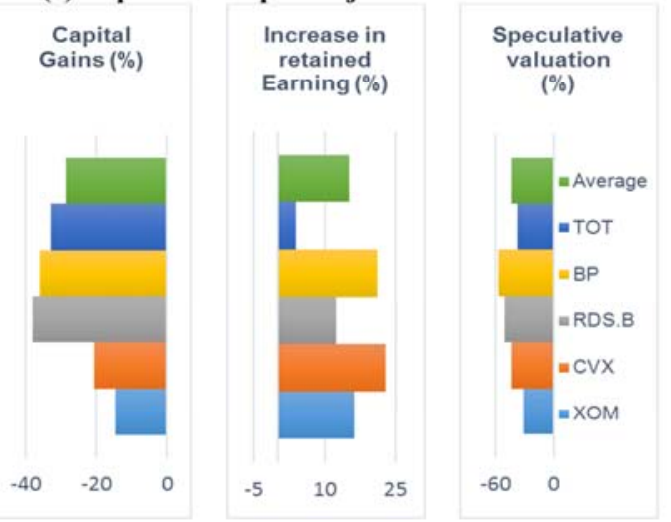

that in 2008 all companies still had strong retained earnings but capital loss was steep due to large negative speculative valuations. In 2014 retained earnings were more than halved but the reaction of investors did not lead to the excessive negative speculation seen in 2008. As a result, share capital losses in 2014 were much less than in 2008 and TSR did not decline as much in 2014 as in 2008 (Figs. 6a and6b). In the 2014 recession, Shell achieved a small increase in retained earnings $(2.01 \%)$; however due to having the least negative speculative valuation $(-9.40 \%)$ the company still achieved only a modest loss of share capital $(-7.39 \%)$. BP had a much smaller increase in retained earnings $(1.95 \%)$ but the largest negative speculative valuation $(-23.53 \%)$ that caused loss of share capital $(-21.58 \%)$. TOTAL obtained the second largest capital loss $(-16.44 \%)$ because it was the only company that had an actual decrease in retained earnings (-3.67\%). Despite the declining increase in retained earnings from the 2008 to the 2014 recession, capital loss was more limited in 2014 because of less negative speculative valuation in 2014 .

(b) Capital Loss Split Majors 2014 Price Shock

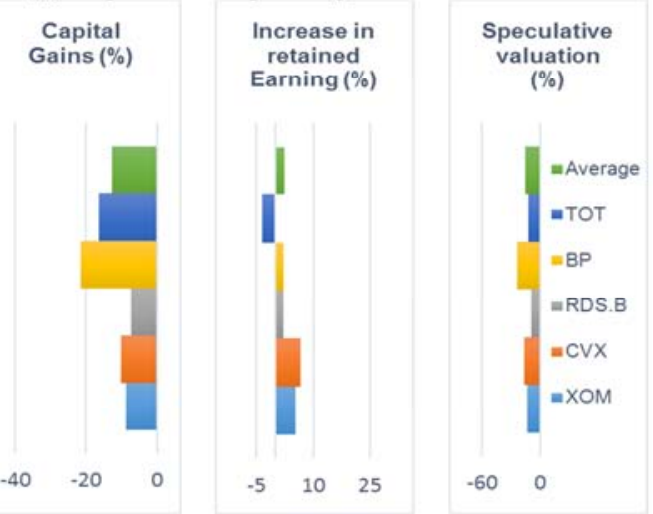

Fig. 6. $a$, $b$-Increase in retained earnings and speculative valuation for diversified oil and gas majors over the two oil price shock events: (a) 2008 and (b) 2014. Increase in retained earnings minus capital gains is equal to speculative valuation.

\subsection{Canadian Oil Sands Producers (Peer Group B)}

A) TSR During the Oil Price Shocks of 2008 and 2014

The negative TSR during the two price shock events for peer group B occurred due to the decline of stock prices which resulted in negative capital gains (capital losses; Figs. $7 \mathrm{a}$ and $7 \mathrm{~b}$ ). For example, in 2008 the sum of the least capital loss $(-38.44 \%)$ and the highest dividends $(1.06 \%)$ resulted in the best TSR (-37.39\%) for Imperial Oil. Suncor Energy had 
the worst TSR $(-63.18 \%)$ caused by having the largest capital loss (-64.13\%). In 2014, Suncor Energy continued with the lowest TSR $(-6.42 \%)$; although it had the highest dividends $(2.91 \%)$, it had the largest capital loss $(-9.33 \%)$. Imperial Oil again showed the least decline in TSR $(-1.62 \%)$ of peer the group, and although paying the smallest dividends (1.09\%), the retained loss was also small $(-2.71 \%)$. The TSR in 2008 was $43.63 \%$ lower than the TSR in 2014 because of the much larger decline of stock prices during the first recession.

(a) TSR Split Oil Sands 2008 Price Shock

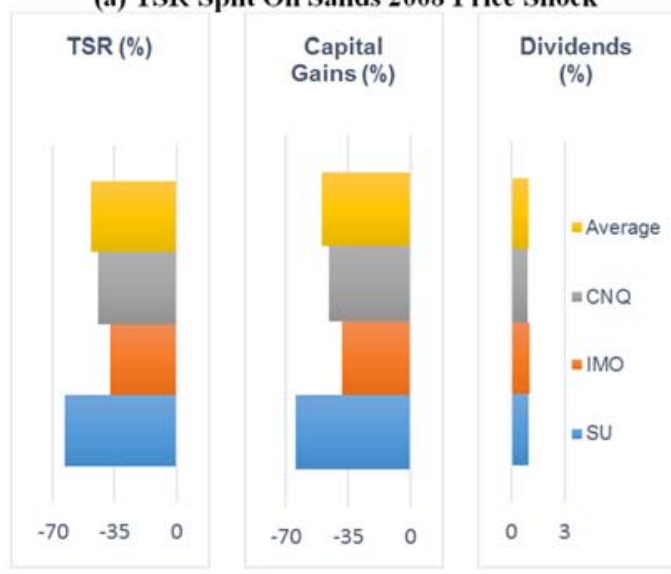

B) Change in Retained Earnings and Speculative Valuation During 2008 and 2014 Oil Price Shocks

The capital gains and its principal components (change in retained earnings and speculative valuation) for Canadian oil sands producers were studied for the 2008 (Fig. 8a) and 2014 crises (Fig. 8b). During the 2008 crisis, all companies of peer group B presented large losses of share capital primarily caused by the negative speculative valuation in combination with negligible profits (retained earnings). Only Canadian

(b) TSR Split Oil Sands 2014 Price Shock

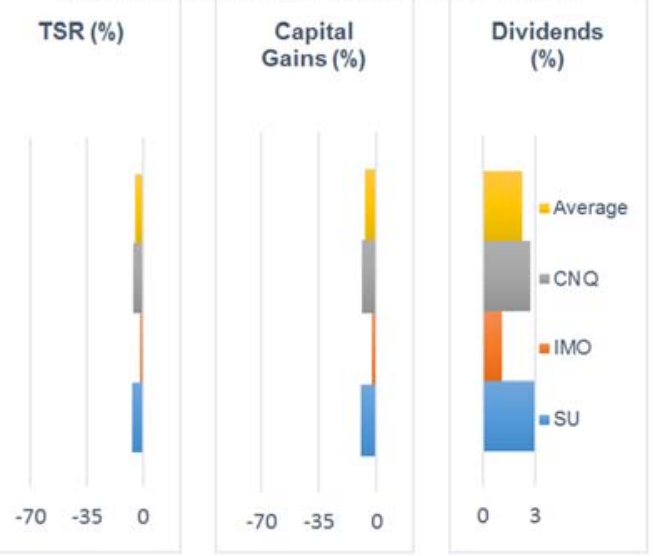

Fig. 7. a, b-TSR for Canadian oil sands producers over the two oil price shock events: (a) 2008 and (b) 2014. Breakdown of TSR (\%) contribution by each of the two components: (1) capital gains and (2) dividend yield.

Natural Resources had a positive increase in retained earnings (18.24\%); however the company had the largest negative speculative valuation $(-63.58 \%)$ which resulted in the capital loss $(-45.34 \%)$ in the middle of the peer group.

The least negative speculative valuation $(-36.18 \%)$ was obtained by Imperial Oil which also had the least capital loss $(-38.44 \%)$. Although Suncor was the only company that had a decrease in retained earnings $(-4.20 \%)$, it received the second largest negative speculative valuation (-59.94\%) which caused the largest capital loss (-64.13\%).

As in the 2008 crisis, in 2014 all companies had negative capital gains mainly caused by negative speculative

(a) Capital Loss Split Oil Sands 2008 Price Shock

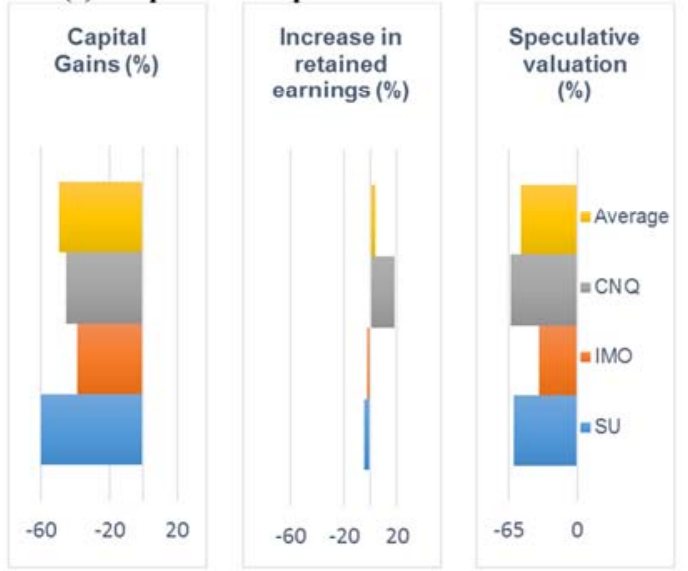

valuations. However the capital loss in 2014 was much smaller than in 2008. Although Suncor Energy obtained the least negative speculative valuation $(-1.63 \%)$, it is the only company that had a decrease in retained earnings $(-7.70 \%)$ which resulted in the largest capital loss (-9.33\%). Despite large negative speculative valuation (-10.20\%), Imperial Oil achieved the least loss of share capital (-2.71\%) due to the highest increase in retained earnings (7.49\%). The less negative speculative valuation in 2014 and modest changes in retained earnings for most of the companies resulted in a less dramatic loss of share capital as compared to the 2008 crisis.

(b) Capital Loss Split Oil Sands 2014 Price Shock

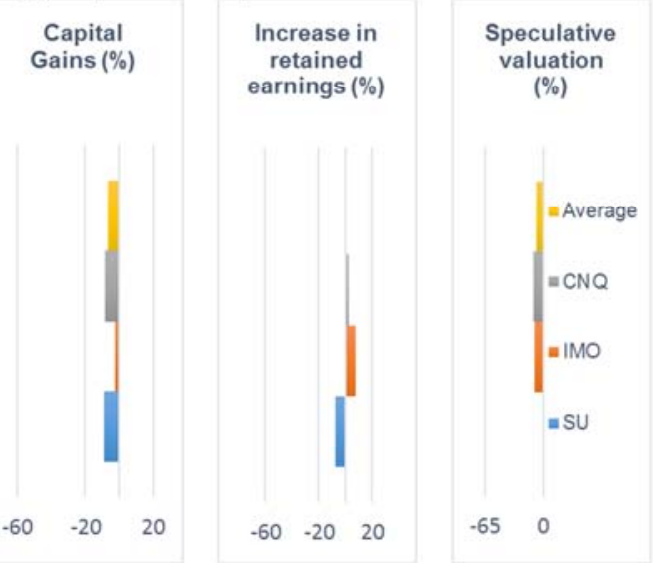

Fig. 8. a, b-Increase in retained earnings (\%) and speculative valuation (\%) for Canadian oil sands producers over the two oil price shock events: (a) 2008 and (b) 2014. Increase in retained earnings minus capital gains (capital loss) is equal to speculative valuation. 


\subsection{US Shale Oil and Gas Producers (Peer Group C)}

A) TSR During the Oil Price Shocks of 2008 and 2014

Figs. 9a and $9 \mathrm{~b}$ show the TSR for US shale oil and gas producers over the 2008 and 2014 recession. The vast majority of the companies delivered negative TSR during both crises. In 2008, Southwestern Energy was the only company with a positive TSR (3.98\%) due to modest positive capital gains (3.98\%). All other companies had negative TSR. Carrizo had the largest negative TSR (-70.59\%) due to the largest capital loss $(-70.59 \%)$ and zero dividends. During the 2008 crisis, Encana paid the highest dividends (6.34\%) of the decade and diminished the loss in TSR $(-25.19 \%)$. The 2014 crisis caused different impacts on the US shale oil and

(a) TSR Split US Shale Producers 2008 Price Shock

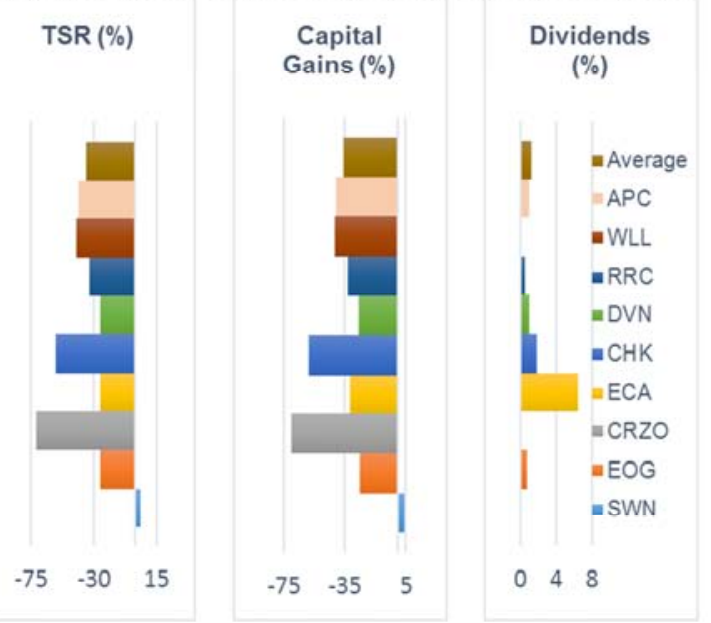

gas producers, and the TSR values vary widely among the companies during this latest recession. Anadarko and EOG maintained positive TSR $(5.21 \%$ and $10.27 \%$, respectively) due their positive capital gains $(4.01 \%$ and $9.71 \%)$. Although Devon had negative capital gains (-1.07\%), the company also realized positive TSR $(0.47 \%)$ by awarding a relatively large dividend $(1.54 \%)$. Whiting Petroleum Corporation had the worst result by combining the largest capital loss $(-46.66 \%)$ with zero dividends. Some companies increased and other decreased their TSR from 2008 to 2014. Analyzing the whole group, the impact in 2014 was less severe than in 2008, and the TSR in the first crisis was $18.4 \%$ lower than in 2014.

(b) TSR Split US Shale Producers 2014 Price Shock

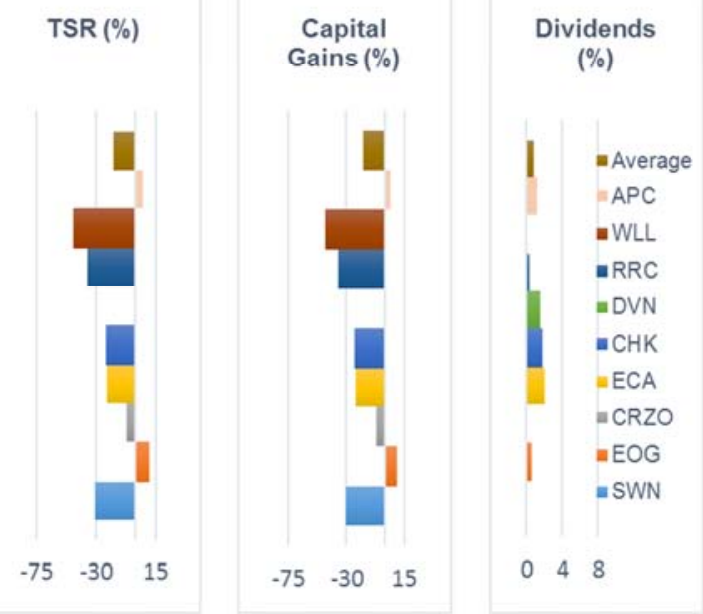

Fig. 9. $a, b$-TSR for US shale oil and gas producers over the two oil price shock events: (a) 2008 and (b) 2014. Breakdown of TSR contribution by each of the two components: (1) capital gains and (2) dividend yield.

B) Change in Retained Earnings and Speculative Valuation During 2008 and 2014 Oil Price Shocks

The capital gains and its components (increase in retained earnings and speculative valuation) for US shale oil and gas producers were analyzed for the 2008 (Fig. 10a) and 2014 crises (Fig. 10b). During the 2008 crisis, most of the companies had negative capital gains due to the large negative speculative valuation. Southwestern Energy was the only company that presented positive capital gains (3.98\%). The company had the second highest increase in retained earnings (64.40\%) and the third least negative speculative valuation (-60.41\%). For 2008, Carrizo and Devon were the only two companies that presented a loss in retained earnings. Devon had the second largest loss of retained earnings (-19.02\%); however due to the second least negative speculative valuation $(-7.07)$, the loss of share price ($26.09 \%$ ) was lower than the year peer group average ($36.09 \%$ ). Despite having the least negative speculative valuation (-1.66\%), Carrizo had the largest operational loss ($68.93 \%$ ) which resulted in the largest share loss of share capital (-70.59\%). Range Resources showed the largest negative speculative valuation (-117.45\%); however the company had share capital loss (-33.04\%) lower than the average loss (-36.09\%) because of the best increase in retained earnings $(84.41 \%)$.

During the 2014 recession, the companies of peer group C obtained negative speculative valuation although they still increased their retained earnings, excepting Anadarko. Despite the loss of retained earnings (-15.54\%), the latter company had a positive speculative valuation (19.55\%) that resulted in positive capital gains (4.01\%). EOG achieved the best capital gains $(9.71 \%)$ due to the least negative speculative valuation ($11.61 \%$ ) and a growth in increase in retained earnings $(21.33 \%)$. The largest negative speculative valuation ($182.17 \%$ ) was obtained by Encana which had the bigger increase in retained earnings (159.01\%). Whiting Petroleum had the largest loss of share capital (-46.66\%) due to the small increase in retained earnings (2.90\%) and large negative speculative valuation (-49.56\%). Carrizo is studied separately during this year because of its different behavior: the company showed a large negative speculative valuation (-590.43\%) and a high increase in retained earnings (583.35\%). The average of capital gains increased because of the growth in increase in retained earnings and from the first to the second period. Despite of the growth in capital gains, the speculative valuation decreased from Period 1 to Period 2. 
(a) Capital Loss Split US Shale Producers 2008 Price Shock

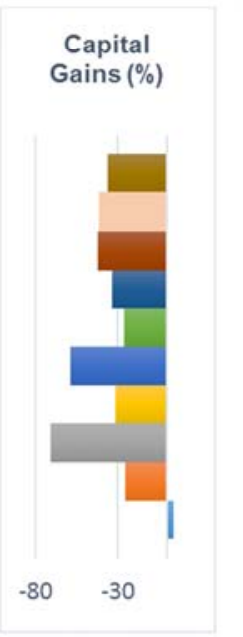

(b) Capital Loss Split US Shale Producers

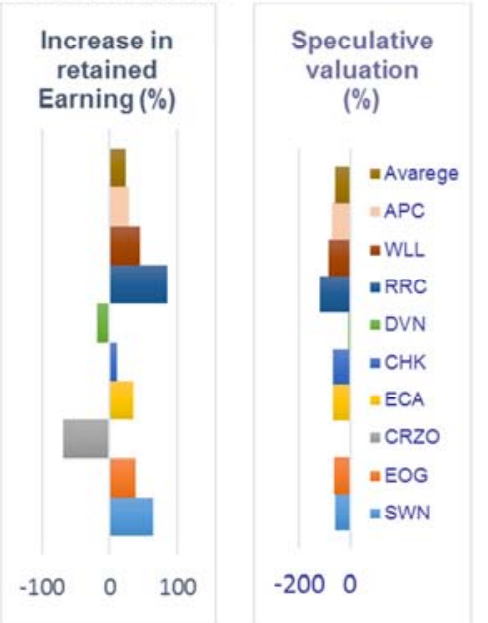

\section{Price Shock}

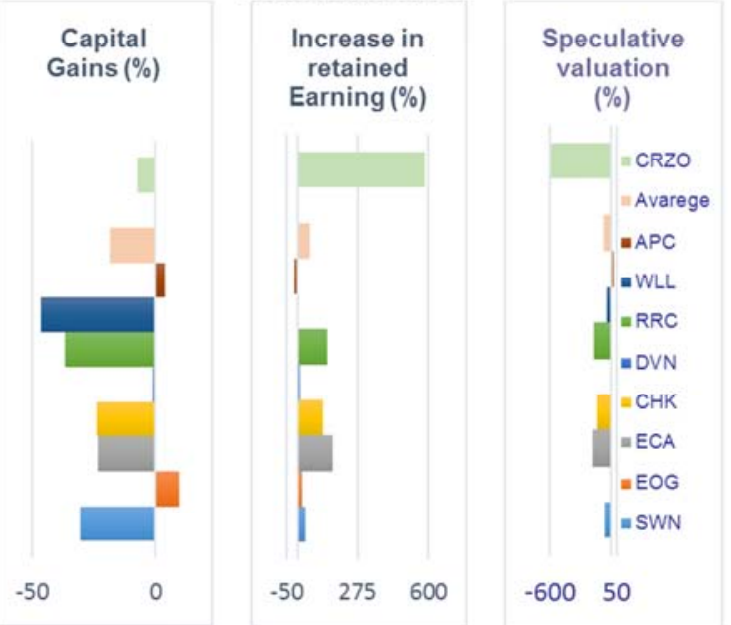

Fig. 10. $a$, $b$-Increase in retained earnings and speculative valuation for US shale oil and gas producers over the two oil price shock events: (a) 2008 and (b) 2014. Increase in retained earnings minus capital gains is equal to speculative valuation. Due to the different behavior of CRZO, the average peer group is calculated without this company.

\subsection{Oilfield Services (Peer Group D)}

A) TSR During the Oil Price Shocks of 2008 and 2014

In 2008 (Fig. 11a), all oilfield services had negative TSR because of negative capital gains. In 2008, Baker Hughes had the largest TSR loss $(-58.71 \%)$, due to posting the smallest dividends (1.75\%) and largest loss of share capital ($60.46 \%$ ). Halliburton had better results in this year, awarding the same dividend as Schlumberger (1.98\%), but achieving lower losses of share capital $(-52.04 \%)$ which resulted in a lesser decline of TSR (-50.06\%). In 2014 (Fig. 11b), Baker Hughes was announced as a takeover target by Halliburton which has affected the TSR of these oilfield service companies. The acquisition announcement was reviewed by the US Department of Justice, which rejected the merger in 2016. Nonetheless, the mere announcement of the merger

(a) TSR Split Oil Services 2008 Price Shock

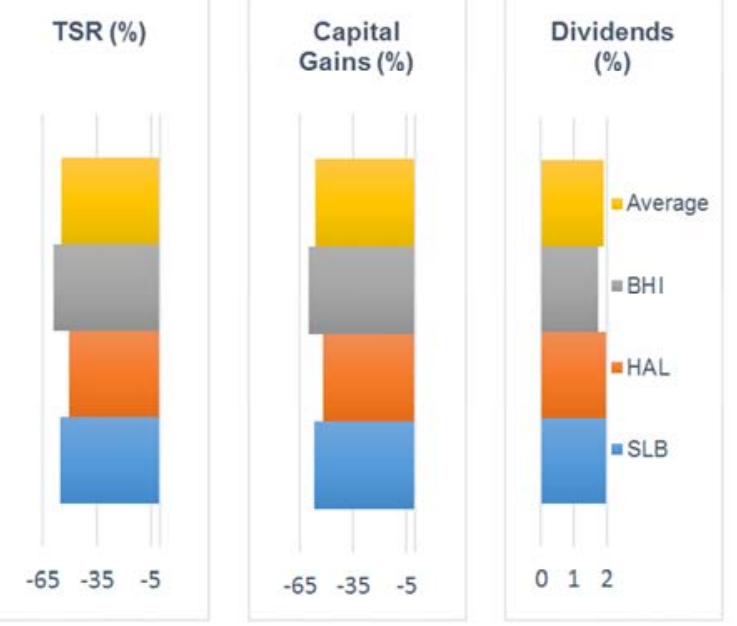

had a positive impact on Baker's2014 financial indicators, but was costly for Halliburton, especially because the transaction coincided with the time when oil prices fell dramatically. Despite the 2014 oil price crisis, Baker Hughes achieved positive TSR (2.61\%) which was due to a 2014 stock price increase (caused by the merger plan) and resulted in positive capital gains. Although the increase in stock price was small it was enough to result in positive capital gains $(2.61 \%)$. In contrast, Halliburton presented the worst performance of the group, as the decrease in its stock price caused the negative TSR (-20.90\%). Ultimately the 2014 oil price crisis was less damaging than the 2008 recession. Both events were accompanied by higher dividends than the two stable periods studied before. Despite of the high dividends, the stock prices have fallen in 2014, resulting in TSR losses, except for Baker Hughes.

(b) TSR Split Oil Services 2014 Price Shock

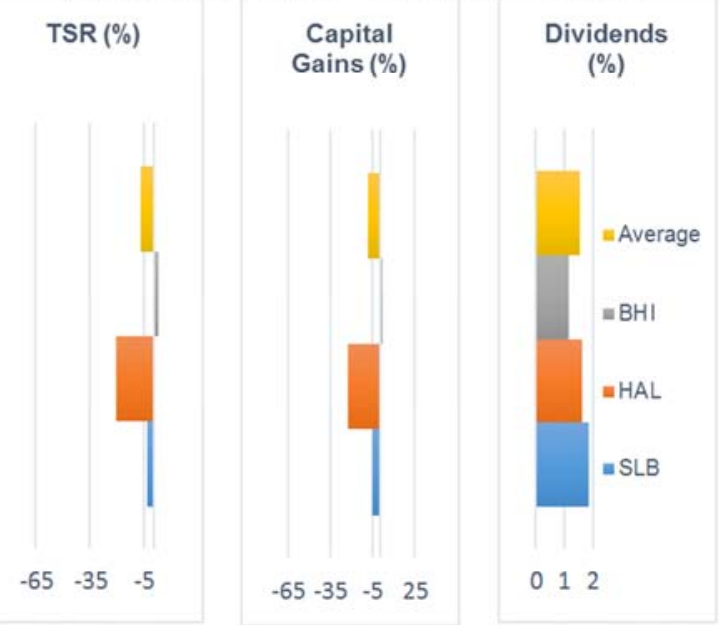

Fig. 11. a, b-TSR for oilfield services over the two oil price shock events: (a) 2008 and (b) 2014. Breakdown of TSR contribution by each of the two components: (1) capital gains and (2) dividend yield. 
(a) Capital Loss Split Oil Services 2008 Price Shock

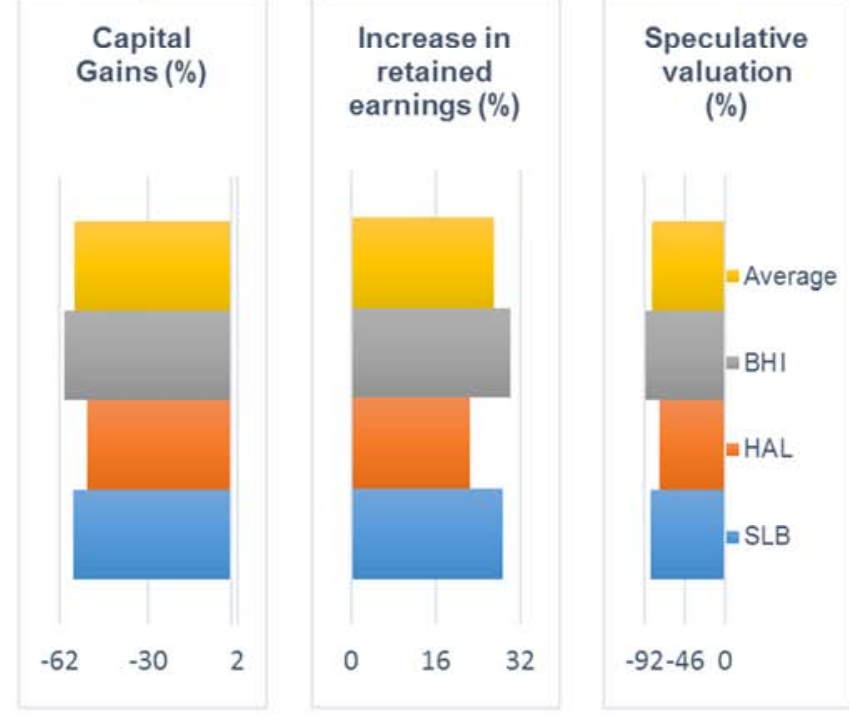

(b) Capital Loss Split Oil Services 2014 Price Shock

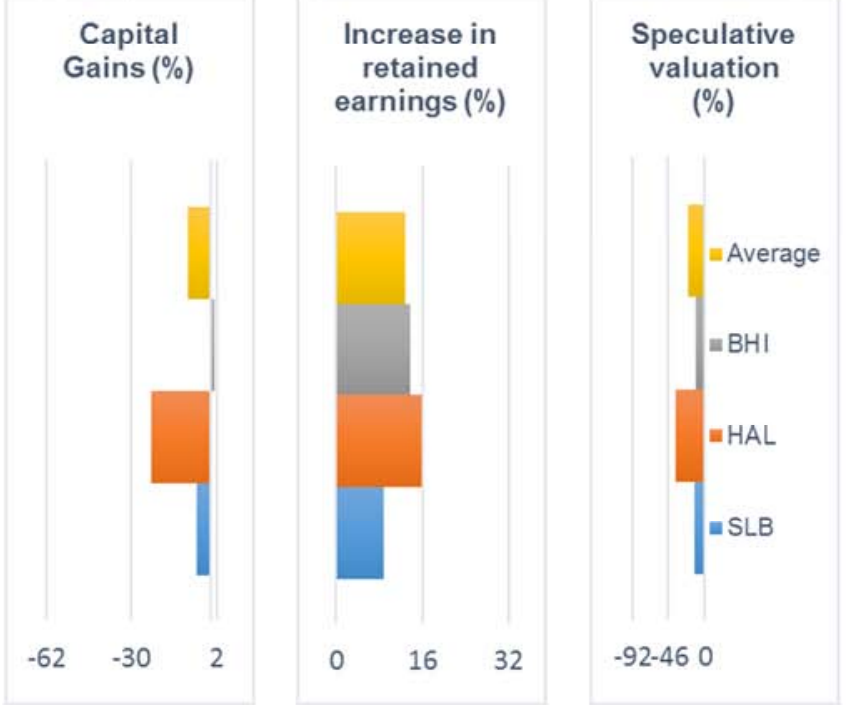

Fig. 12. $a, b$-Increase in retained earnings and speculative valuation for oilfield services over the two oil price shock events: (a) 2008 and (b) 2014. Increase in retained earnings minus capital gains is equal to speculative valuation.

B) Change in Retained Earnings and Speculative Valuation During 2008 and 2014 Oil Price Shocks

The capital gains and its components (increase in retained earnings and speculative valuation) for oilfield services are presented in Fig. 12a (2008 crisis) and in Fig. 12b (2014 crisis). During the 2008 crisis, the service companies received large negative speculative valuation from investors; consequently, they realized negative capital gains in spite large positive retained earnings. Halliburton had the least negative speculative valuation $(-74.47 \%)$ that resulted in the least capital loss $(-52.04 \%)$ even though this was accompanied by the lowest increase in retained earnings $(22.42 \%)$. In contrast, Baker Hughes achieved the highest increase in retained earnings $(30.26 \%)$, and due to the largest negative speculative valuation (-90.72\%) lost share capital ($60.46 \%$ ), In 2014, Baker Hughes was the only company that obtained positive capital gains $(1.47 \%)$, caused by the least negative speculative valuation $(-12.33 \%)$ and the high increase in retained earnings $(13.80 \%)$. On other hand, Halliburton received the largest negative speculative valuation $(-38.25 \%)$ which resulted in the largest capital loss $(-22.50 \%)$, despite the highest increase in retained earnings (15.75\%). The capital loss in the 2014 crisis remained limited due to the decrease in negative speculative valuation from the 2008 to 2014 crisis, in spite of a reduction in the increase in retained earnings from the first to the second recession.

\section{Discussion}

We analyzed the TSR decline of 20 upstream petroleum companies and oil service companies during the oil price shocks of 2008 and 2014. All 20 companies in our peer groups suffered negative TSR (losses) in 2008 and 2014 [except for Anadarko, Baker Hughes, and EOG resources, all of which yielded positive TSR (gains) in 2014]. Share value erosion was markedly larger in 2008, resulting in 30\% higher TSR loss than in 2014. We separated for each company the TSR in its capital gains and dividend portions. For all companies loss of share value was generally higher in 2008 as compared to 2014 . We next examined how the percentage of capital loss was underpinned by changes (increase/decrease) of retained earnings. Any mismatch was quantified as a speculative valuation of the shares, either negative or positive.

In 2008, oil majors realized significant retained earnings growth but negative speculative valuation resulted in TSR losses - in spite of dividend payments (Fig. 6a). The same companies had negligible growth (or even loss) of retained earnings in 2014, but the TSR loss was much lower for shareholders in 2014 as compared to 2008, because negative speculative valuation was much less severe in 2014 (Fig. 6b).

Shareholders in Canadian oil sands suffered steep losses in 2008 , but less than $10 \%$ in 2014 . For oil sand companies, changes in retained earnings were negligible in both 2008 and 2014, but steep negative valuation caused their TSR loss in 2008 (Fig. 8a). In 2014, such negative speculation remained absent, resulting in less than $10 \%$ loss of TSR (Fig. 8b).

Shareholders in shale producers in the US suffered significant capital losses in both 2008 and 2014, except for shareholders in Anadarko (APC) and EOG Resources who realized capital gains in 2014 (Figs. 9a,b). Most companies reported increases in retained earnings, but negative speculative valuation lead to TSR losses in both 2008 and 2014 (Fig. 10a,b). Shareholders in oil service companies experienced TSR losses in 2008, but TSR erosion remained limited in 2014 (Fig. 11a,b). Massive negative speculative valuation was responsible the capital loss of 2008 (in spite of strong growth in retained earnings (Fig. 12a). Negative speculation was less severe in 2014, which is why capital loss remained limited partly because retained earnings still grew in 2014 (Fig. 12b). 
Our present analysis shows that speculative valuation seems to show no clear correlation with dividend payments. What does appear is that negative speculative valuation is responsible for erosion of TSR when oil stocks drop during steep oil price fall events. Investors apparently braced themselves for future profit/losses by selling stock, which in turn drives down share prices. The underlying profit growth remained robust for most companies both in 2008 and in the following years as graphed for each set of peer group companies in Figs. 13a-d. The plots also reveal that shale companies show the more volatile change in retained earnings. Of all peer groups studied, shale companies reported the largest TSR losses in both 2008 and 2014. Such smaller emergent companies commonly cannot cover growth from operational earnings alone and remain critically dependent on external financing to expand the project portfolio [10].

\section{(a) Oil and Gas Majors}

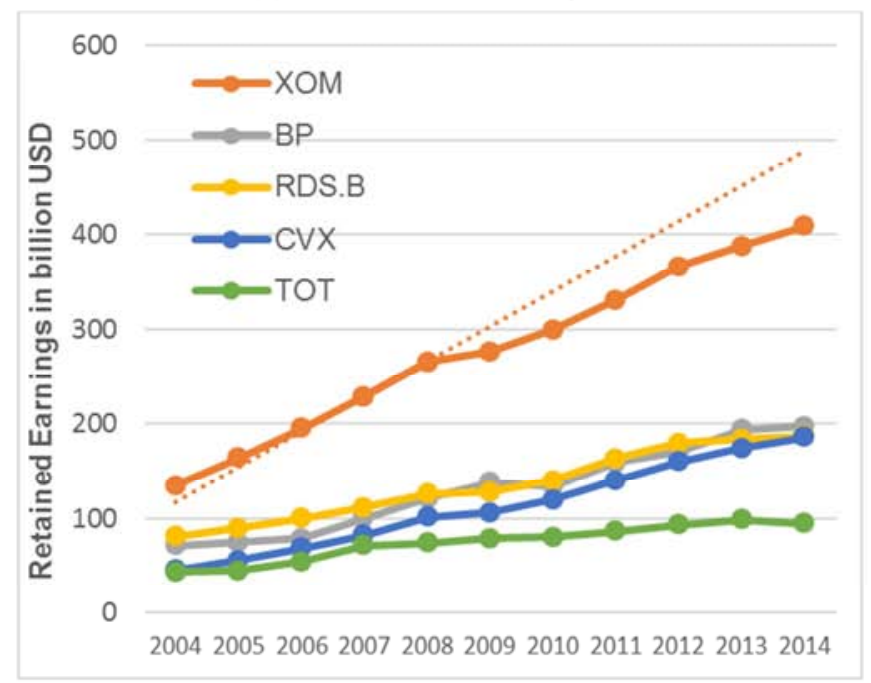

(c) US Shale Producers

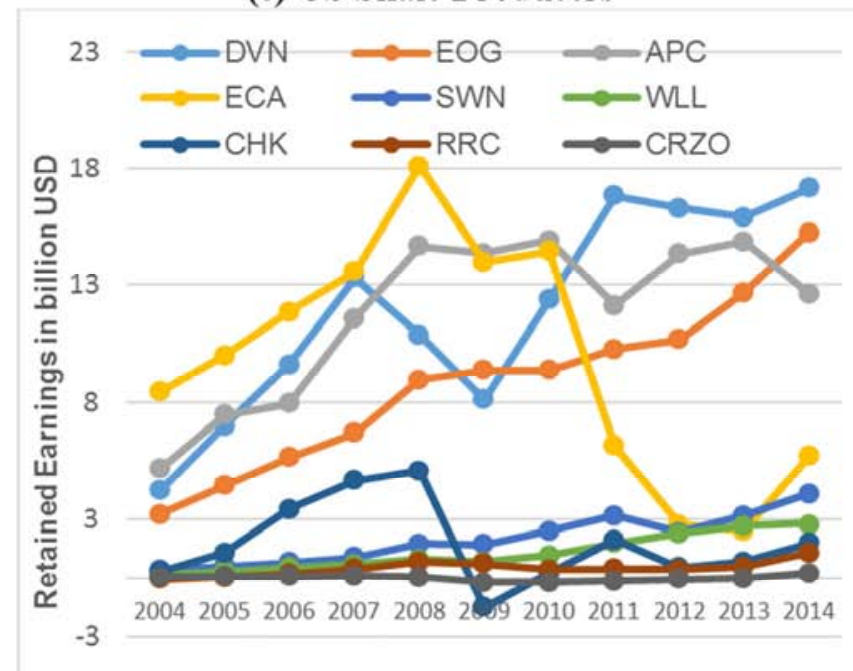

Investors are used to look at price/earnings $(\mathrm{P} / \mathrm{E})$ ratios to determine whether a company is potentially undervalued or overvalued [9]. In times of accumulative losses, earnings are negative, which results in negative $\mathrm{P} / \mathrm{E}$ ratios. Such complications make it difficult to asses the up or downside potential of stocks based on $\mathrm{P} / \mathrm{E}$ ratios when markets are in distress. Our article argues a more consistent view of a company's performance and future potential is obtained by comparing growth in retained earnings with growth in the capital gains portion of TSR. If retained earnings continue to grow, share price decline is purely speculative and not immediately supported by the underlying fundamentals. For all 20 companies studied, the oil price shocks (price fall) of 2008 did not lead to cumulative losses; retained earnings continued to grow albeit at a slower pace (Figs. 13a-d).

\section{(b) Canadian Oil Sands}

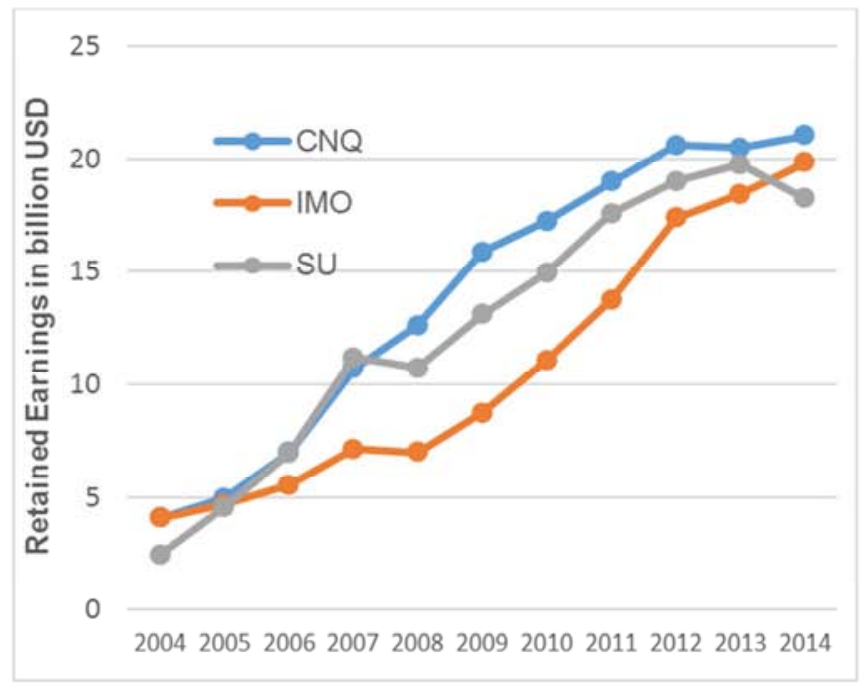

(d) Oil Services

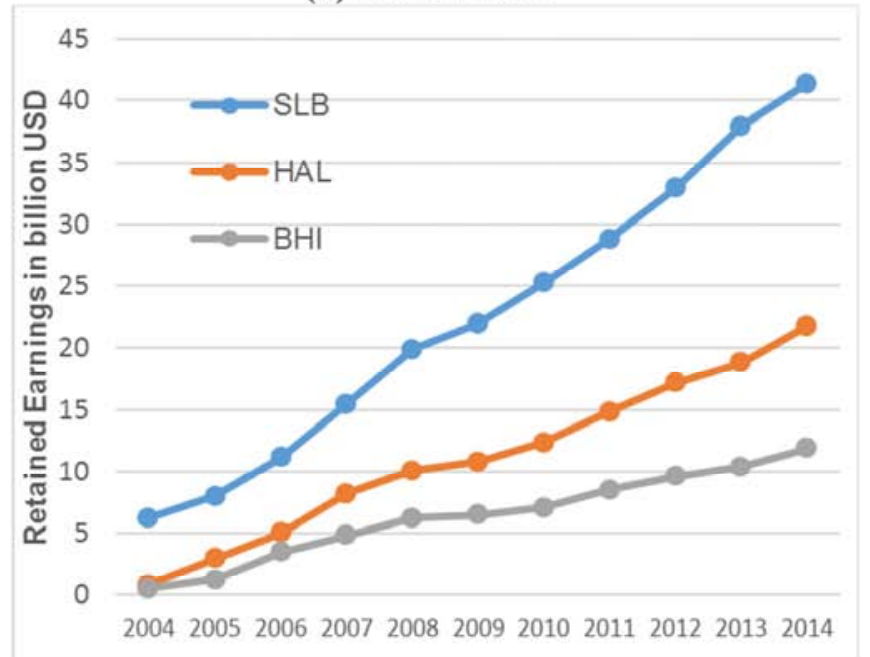

Fig. 13. a-d-Annual retained earnings (billion USD) for individual companies in each of the peer groups (A-D) over the past decade (2004-2014). After Bocardo and Weijermars [1]. 


\section{Conclusion and Recommendations}

\subsection{Recommendations for Investors}

Our analysis of TSR erosion during the oil price shock of 2008 suggests that negative speculative valuation is expressed by stock sell-off that discounts the stock price of oil and gas companies is not justified when the underlying profit generation capacity (retained earnings growth) of these companies remains little affected in that year and in subsequent years. Share prices eventually recovered, which means short-term sell-off penalizes selling investors as compared to those who hold on to their stock. We advise that stockholders who do not bail out from their upstream oil and gas stockholdings during the early stages of an oil price fall sit tight and hold on to their stocks through the epoch of the oil price shock. Alternatively, stockholders selling off petroleum stocks in the early stages of an oil price fall for direct reinvestment in stocks of other sectors may realize an average S\&P reference TSR that indeed outperforms the petroleum TSR, in analogy with what occurred with their respective TSRs after the 2008 oil price shock (Fig. 1b). Opportunity investors who have cash positions available should time stock purchases to coincide with the share devaluation due to negative speculative valuation when the underlying profit generation capacity (retained earnings growth) of these companies remains little affected by the downturn.

\subsection{Recommendations for Company Management}

Petroleum companies will inevitably suffer strong share price erosion and TSR losses in periods of oil price shocks, in spite of any sustained growth in their fundamental performance (such as growth in retained earnings). Company management should consider expressing the current and anticipated growth in retained earnings as an expected capital gains of TSR in current and future years (excluding the effect of speculative valuations). Separately, our analysis suggest in times of recessional markets investor behavior is less lead by fundamentals and more by a "fear of loss" factor prompted by daily headlines rather than long-term analysis of the corporate financial fundamentals. Given this conclusion, companies should consider marketing aggressively for shareholder appeal, especially in times of steep share price falls. for those investors who do appreciate fundamentals, we suggest analyzing retained earnings and speculative valuation underlying the change in capital gains portion of TSR provides a strong indicator of the future potential of TSR recovery. When negative speculative valuation is large, future TSR growth opportunities are most likely. Such facts should be spelled out by companies via their intermediary stockbrokers in order to correct unwarranted fall in their stock price.

\section{Acknowledgements}

Terri Smith is thanked for her editing. Anita Bocardo was sponsored by a CAPES (Coordination for the Improvement of Higher Education) scholarship - Brazil, CSF (science without borders) program.

\section{References}

[1] Bocardo, A. B., and Weijermars, R., 2015. Total Shareholder Returns from Petroleum Companies and Oilfield Services (2004-2014): Capital Gains and Speculation Dissected to Aid Corporate Strategy and Investor Decisions. Journal of Finance and Accounting, in press.

[2] Rodrigues, R. and Weijermars, R., 2016. Assessing the impact of two recessions on the oil and gas industry: severity of declines and future outlook. First Break, vol. 34 (1), $79-85$.

[3] Institute of Management accountants. IMA, 1997. Measuring and Managing Shareholder Value Creation. Statements on Management Accounting., 39 pages. http://www.imanet.org/ docs/default-ource/thought_leadership/ management_control_ systems/measuring_and_managing_shareholder_value_ creation.pdf?sfvrsn $=2$ (accessed 22 July 2015).

[4] Weijermars, R., and Watson, S., 2011. Unconventional Natural Gas Business: TSR Benchmark and Recommendations for Prudent Management of Shareholder Value. SPE Economics \& Management, 3 (4) p. 247-261, SPE-54056-PA. http://dx.doi.org/10.2118/154056-PA.

[5] Chartered Institute of Management Accountants (CIMA), 2004. Maximizing Shareholder Value Achieving clarity in decision-making. Technical Report. The Chartered Institute of Management Accountants, 28 pages. http://www.cimaglobal. com/Documents/Thought_leadership_docs/MigratedDocsMar ch2010/Resouces\%20(pd $\overline{\mathrm{fs}}$ )/Technical\%20reports/Maximising shareholder_value_achieving_clarity_in_decisionmaking.pdf (accessed 22 July 2015$)$.

[6] Pirog, R. 2012. Financial performance of the Major Oil Companies, 2007-2011. U.S. Congressional Research Service. February 17, 2012. https://www.fas.org/sgp/crs/misc/R42364. pdf (accessed 22 July 2015)

[7] Wallace, J. S., 2003, Value Maximization and Stakeholder Theory: Compatible or not? Journal of Applied Corporate Finance, 15 (3), Spring. http://onlinelibrary.wiley.com/ doi/10.1111/j.1745-6622.2003.tb00466.x/pdf

[8] Burgman, R., and Van Clieaf, M., 2012. Total shareholder return and management performance: A performance metric appropriately used, or mostly abused? Rotman International Journal of Pension Management, 5 (2): 1-8 (Fall). DOI: 10.3138/rijpm.5.2.26

[9] Beaver, W. and Morse, D., 1978. What determines PriceEarnings ratios? Financial Analyst Journal, 34 (4), p. 65-76. http://www.jstor.org/stable/4478160 (accessed 22 July 2015).

[10] Weijermars, R., 2011. Credit ratings and cash-flow analysis of oil and gas companies: competitive disadvantage in financing costs for smaller companies in tight capital markets. SPE Economics \& Management, 3(02), 54-67. SPE-144489. doi:10.2118/144489-PA. 